\title{
Sex Steroid Hormone Receptors in Human Skin Appendage and its Neoplasms
}

\author{
YOSHIYUKI KARIYA*, TAKUYA MORIYA**, TAKASHI SUZUKI*, MARIKO CHIBA*, KAZUYUKI ISHIDA**, \\ JUNJI TAKEYAMA*, MAREYUKI ENDOH**, MIKA WATANABE** AND HIRONOBU SASANO*,** \\ *Department of Pathology, Tohoku University School of Medicine, Sendai 980-8574, Japan \\ **Department of Pathology, Tohoku University Hospital, Sendai 980-8574, Japan
}

\begin{abstract}
Sex steroids have been postulated to influence pathophysiology of human skin through various skin appendages. The presence of sex steroid receptors has been also reported in adnexal tumors but its details still remained unknown. Therefore, in this study, we immunolocalized sex steroid receptor protein (estrogen receptor (ER) $\alpha$, ER $\beta$, progesterone receptor (PR)A, PRB and androgen receptor (AR)) in 23 cases of non-pathological skin (male: 10, female: 13 ) and in 50 cases of skin adnexal tumors (male 24, female 26; 38 benign and 12 malignant). ER $\alpha$ immunoreactivity was detected exclusively in basal cells of sebaceous glands of non-pathological skin. AR and PRB immunoreactivity was detected in both differentiated and basal cells of sebaceous gland. AR and ER $\beta$ immunoreactivity was also detected in sebaceous and eccrine sweat glands but not in outer root sheath of hair follicles. In sebaceous gland neoplasms, the number of ER $\alpha$ positive cases was significantly lower in skin appendage neoplasms than non-pathological skin. ER $\beta$ immunoreactivity was not detected in any of sebaceous gland neoplasms examined. There were no significant differences in PRA, PRB and AR immunoreactivity between non-pathological sebaceous gland and its neoplasm. In sweat gland neoplasms, the number of AR positive cases was significantly lower in benign neoplasms than their non-pathological counterpart. Therefore sex steroids are considered to play important roles in regulation of non-pathological skin appendage function and pathogenesis and/or development of its neoplasm. In addition, the status of the great majority of sex steroid hormone receptors was maintained throughout the process of neoplastic transformation of skin appendages, except for AR and ER $\alpha$ in sweat and sebaceous gland neoplasms.
\end{abstract}

Key words: Hormone receptor, Sex steroid hormone, Skin appendage, Neoplasm, Immunohistochemistry

(Endocrine Journal 52: 317-325, 2005)

IT is well-known that sex steroids play important roles in development and/or physiology of human mammary glands [1-3]. In addition, abnormalities of sex steroid metabolism are also considered to be involved in development and/or biological behavior of mammary gland neoplasms. Human sweat gland is analogous to the mammary gland in its development and/or physiology [4]. Therefore, non-pathological human sweat glands and their neoplasms may share similar characteristics with mammary glands and its tumors in terms

Received: July 7, 2004

Accepted: January 31, 2005

Correspondence to: Yoshiyuki KARIYA, M.D., Department of Pathology, Tohoku University Hospital, 1-1 Seiryo-machi, Aobaku, Sendai 980-8574, Japan of influence by sex steroids. Sex steroids have been implicated in the development of acne in puberty [5-8], moisturizing of skin or epidermis in women [9-12] and others. In addition, previous studies demonstrated that some skin appendage tumors were positive for sex steroid hormone receptors [13-22]. The studies of Thornton et al. and Shin et al. both demonstrated that immunoreactivity of some sex steroid hormone receptors in human scalp skin [23, 24]. However, the precise distribution of steroid hormone receptors in nonpathological human skin and/or skin appendage neoplasms has remained virtually unknown. Therefore, in this study, we immunolocalized ER (ER $\alpha$ and ER $\beta)$, PR (PRA and PRB), and androgen receptor (AR) in normal human skin appendages from both male and female subjects obtained from surgery as well as vari- 
ous skin appendage tumors in order to examine the possible involvement of sex steroids in physiology and/or pathology of human skin appendage and its neoplasms.

\section{Material and Methods}

Fifty cases of skin appendage neoplasms ( 38 benign and 12 malignant) and 23 cases of non-pathological skin tissue were retrieved from surgical pathology files at Tohoku University Hospital, Sendai, Japan between 1990 and 2001. Cases of skin appendage tumors examined were 24 males and 26 females, with a mean age of 59.0 years (range: 0 to 86, median: 66). Nonpathological skin tissue specimens were obtained from various parts of the body and from 10 male and $13 \mathrm{fe}-$ male subjects with a mean age of 44.8 years (range: 1 to 80 , median: 49). The histological subtypes of skin appendage neoplasms examined in this study are summarized in Table 1. Non-pathological skin tissue specimens were obtained from patients undergoing surgical excision of skin lesion with informed consent of the patients. This study protocol was approved by the Ethics Committee of Tohoku University School of Medicine, Sendai, Japan (protocol \#2001-240).

All specimens had been fixed in $10 \%$ formalin-fixed for 24 to 36 hours at room temperature, embedded in paraffin, sliced at $3.0 \mu \mathrm{m}$ thickness, and mounted on MAS-coated glass slides (Matsunami Co. Ltd., Tokyo,

Table 1. Summary of skin appendage neoplasms, examined

\begin{tabular}{clc}
\hline \multicolumn{1}{c}{ Histlogic type } & Number \\
\hline Sweat gland tumor $(\mathrm{n}=42)$ & \\
Benign $(\mathrm{n}=30)$ & Eccrine hidroctstoma & 6 \\
& Mixed tumor & 6 \\
& Eccrine poroma & 6 \\
& Syringoma & 3 \\
& Eccrine spiradenoma & 3 \\
& Clear cell hidradenoma & 3 \\
& Syringocystadenoma papilliferum & 2 \\
& Apocrine adenoma & 1 \\
Malignant $(\mathrm{n}=12)$ & Extramammary Paget's disease & 7 \\
& Sweat gland cardcinoma & 4 \\
& Microcystic adnexal carcinoma & 1 \\
Sebaceous gland tumor & $(\mathrm{n}=8)$ & \\
Benign $(\mathrm{n}=8)$ & Sebaceous adenoma & 3 \\
& Sebaceoma & 3 \\
& Sebaceous hyperplasia & 2 \\
\hline
\end{tabular}

Japan). The antibodies used in this study are summarized in Table 2. Anti-ER $\alpha$ (6F11, mouse monoclonal antibody) was purchased from Novocastra (Newcastle upon Tyne, UK). Anti-ER $\beta$ (14C8), mouse monoclonal antibody, was purchased from GeneTex (San Antonio, TX). Antibodies against the two isoforms of PR, PRA (hPRa7) and PRB (hPRa2), both mouse monoclonal antibodies, were purchased from NeoMarkers Co. Ltd. (Fremont, CA). Anti-AR (AR411), mouse monoclonal antibody, was purchased from DAKO (Glostrup, Denmark). The slides were then immersed in methanol containing $0.3 \%$ hydrogen peroxide for $30 \mathrm{~min}$ at room temperature in order to block endogenous peroxidase activity. Autoclave treatment for $5 \mathrm{~min}$ at $120^{\circ} \mathrm{C}$ in $0.01 \mathrm{~mol} / \mathrm{L}$ citrate buffer, $\mathrm{pH} 6.0$, was employed after deparaffinization for antigen retrieval [25]. Normal rabbit or goat serum was incubated for $30 \mathrm{~min}$ at room temperature in order to suppress nonspecific staining. Tissue sections were then incubated with the primary antibodies for $18 \mathrm{hr}$ at $4{ }^{\circ} \mathrm{C}$. After washing, tissue slides were incubated with biotinylated anti-mouse immunoglobulin for $30 \mathrm{~min}$ at room temperature, and subsequently incubated with peroxidase-conjugated streptavidin for $30 \mathrm{~min}$ at room temperature, using Histofine Kit (Nichirei, Tokyo, Japan). The antigen-antibody complexes were visualized by immersion in 3,3'diaminobenzidine (DAB) solution $(0.001 \mathrm{M} D A B$, $0.05 \mathrm{M}$ Tris-HCl buffer, $\mathrm{pH} 7.60 .01 \mathrm{M}$ sodium azide and $0.006 \%$ hydrogen peroxidase). The tissue sections were subsequently counterstained with hematoxylin.

For negative controls of immunostain, the sections were incubated with $0.01 \mathrm{~mol} / \mathrm{L}$ phosphate-buffered saline or normal mouse IgG instead of the primary antibodies. No specific immunoreactivity was detected in these tissue sections (data not shown).

Table 2. Summary of primary antibodies employed in this study

\begin{tabular}{|c|c|c|c|c|}
\hline Antigens & $\begin{array}{l}\text { Antibody } \\
\text { clone }\end{array}$ & Source & Dilution & $\begin{array}{l}\text { Antigen } \\
\text { retrieval }\end{array}$ \\
\hline $\mathrm{ER} \alpha$ & $6 \mathrm{~F} 11$ & $\begin{array}{l}\text { Novocastra } \\
\text { (Newcastle, UK) }\end{array}$ & $1: 40$ & Autoclave \\
\hline$E R \beta$ & $14 C 8$ & $\begin{array}{l}\text { GeneTex } \\
\text { (San Antonio, TX) }\end{array}$ & $1: 4000$ & Autoclave \\
\hline PRA & hPRa7 & $\begin{array}{l}\text { NeoMarkers } \\
\text { (Union City, CA) }\end{array}$ & $1: 200$ & Autoclave \\
\hline PRB & hPRa2 & $\begin{array}{l}\text { NeoMarkers } \\
\text { (Union City, CA) }\end{array}$ & $1: 200$ & Autoclave \\
\hline $\mathrm{AR}$ & AR411 & $\begin{array}{l}\text { DAKO } \\
\text { (Glostrup, Denmark) }\end{array}$ & $1: 100$ & Autoclave \\
\hline
\end{tabular}


Nuclear, not cytoplasm, staining on particular skin appendages and skin appendage neoplasm were considered positive in this study [26]. For statistical analysis, we used the Mann-Whitney's U test and KruskalWallis test to compare the ratio of the positive cases between the groups. $P<0.05$ was defined as statistically significant difference.

\section{Results}

\section{Non-pathological skin appendages and epidermis}

The ratio of sex steroid receptor positive cases is summarized in Table 3 and 4 . We could examine only eccrine glands, since normal apocrine glands were not available for examination in this study. The status of sex steroid receptor immunoreactivity in nonpathological skin appendages varied markedly among the cases examined. Both PRB and AR were present in sebaceous glands, and outer root sheath of hair follicles were completely devoid of ER $\beta$ and AR (Fig. 1). The basal cells of sebaceous glands were positive for ER $\alpha$ in 19 (82.6\%) of 23 cases (Fig. 2). ER $\alpha$ immunoreactivity in basal cells was significantly more frequent than sebaceous lobules (differentiated cells of sebocytes) and other skin appendages. ER $\beta$ immunoreactivity varied in sebaceous glands (both differentiated and basal cells) and secretory cells of eccrine sweat glands, and not detected in outer root sheath cells of hair follicles. PRA immunoreactivity was frequently positive in secretory cells of eccrine sweat glands than any other structures of skin appendages examined, but the differences did not reach statistical significance. PRB immunoreactivity was the most frequently detected sex steroid receptor in all non-pathological human skin appendages and among sex steroid receptors examined in this study. AR immunoreactivity was also frequently detected in both sebaceous glands and secretory cells of eccrine glands, but outer root sheath cells

Table 3. The proportion of hormone receptor positive cases in normal skin appendages

\begin{tabular}{lcccrc}
\hline & $\begin{array}{c}\text { Differentiated cells of } \\
\text { sebaceous glands } \\
\text { No. }(\%)\end{array}$ & $\begin{array}{c}\text { Basal cells of } \\
\text { sebaceous glands } \\
\text { No. }(\%)\end{array}$ & $\begin{array}{c}\text { Eccrine } \\
\text { sweat glands } \\
\text { No. }(\%)\end{array}$ & $\begin{array}{c}\text { Outer root sheath of } \\
\text { hair follicles } \\
\text { No. }(\%)\end{array}$ & $\begin{array}{c}\text { Epidermis } \\
\text { No. }(\%)\end{array}$ \\
\hline ER & $2 / 21(9.5)^{\mathrm{a}}$ & $19 / 23(82.6)^{\mathrm{a}, \mathrm{b}, \mathrm{c}}$ & $6 / 21(28.6)^{\mathrm{b}}$ & $9 / 21(42.9)^{\mathrm{c}}$ & $11 / 23(47.8)$ \\
ER $\beta$ & $8 / 18(50.0)^{\mathrm{d}}$ & $4 / 20(20.0)^{\mathrm{e}}$ & $9 / 23(39.1)^{\mathrm{f}}$ & $0 / 22(0)^{\mathrm{d}, \mathrm{e}, \mathrm{f}}$ & $4 / 23(17.4)$ \\
PRA & $6 / 19(31.6)$ & $3 / 21(14.3)$ & $13 / 22(59.1)$ & $5 / 19(26.3)$ & $5 / 23(21.7)$ \\
PRB & $20 / 20(100)$ & $22 / 22(100)$ & $21 / 22(95.5)$ & $16 / 17(94.1)$ & $22 / 23(95.7)$ \\
AR & $20 / 20(100)^{\mathrm{g}}$ & $22 / 22(100)^{\mathrm{h}}$ & $21 / 23(91.3)^{\mathrm{i}}$ & $0 / 21(0)^{\mathrm{g}, \mathrm{h}, \mathrm{i}}$ & $7 / 23(30.4)$ \\
\hline
\end{tabular}

a, b, c: $P<0.01$ d, e, f: $P<0.05 \mathrm{~g}, \mathrm{~h}, \mathrm{i}: P<0.01$

Table 4. The proportion of hormone receptor positive cases in normal skin appendages of male and female

\begin{tabular}{cccccc}
\hline & $\begin{array}{c}\text { Differentiated cells of } \\
\text { sebaceous glands } \\
\text { No. }(\%)\end{array}$ & $\begin{array}{c}\text { Basal cells of } \\
\text { sebaceous glands } \\
\text { No. }(\%)\end{array}$ & $\begin{array}{c}\text { Eccrine } \\
\text { sweat glands } \\
\text { No. }(\%)\end{array}$ & $\begin{array}{c}\text { Outer root sheath of } \\
\text { hair follicles } \\
\text { No. }(\%)\end{array}$ & $\begin{array}{c}\text { Epidermis } \\
\text { No. }(\%)\end{array}$ \\
\hline \multirow{2}{*}{ ER $\alpha$} & $1 / 9(11.1)$ & $9 / 10(90.0)$ & $3 / 8(37.5)$ & $4 / 8(50.0)$ & $4 / 10(40.0)$ \\
& $1 / 12(8.3)$ & $10 / 13(76.9)$ & $3 / 13(23.1)$ & $5 / 13(38.4)$ & $7 / 13(53.8)$ \\
ERß & $4 / 8(50.0)$ & $3 / 9(33.3)$ & $4 / 10(40.0)$ & $0 / 10(0)$ & $2 / 10(20.0)$ \\
& $4 / 10(40.0)$ & $1 / 11(9.1)$ & $5 / 13(38.5)$ & $0 / 12(0)$ & $2 / 13(15.4)$ \\
PRA & $2 / 8(25.0)$ & $1 / 9(11.1)$ & $8 / 10(80.0)$ & $3 / 9(33.3)$ & $3 / 10(30.0)$ \\
& $4 / 11(36.3)$ & $2 / 12(16.7)$ & $5 / 12(41.6)$ & $2 / 10(20.0)$ & $2 / 13(15.4)$ \\
PRB & $9 / 9(100)$ & $10 / 10(100)$ & $10 / 10(100)$ & $7 / 8(87.5)$ & $10 / 10(100)$ \\
& $11 / 11(100)$ & $12 / 12(100)$ & $11 / 12(91.7)$ & $9 / 9(100)$ & $12 / 13(92.3)$ \\
AR & $9 / 9(100)$ & $10 / 10(100)$ & $10 / 10(100)$ & $0 / 9(0)$ & $4 / 10(40.0)$ \\
\end{tabular}

upper low: male; under low: female 


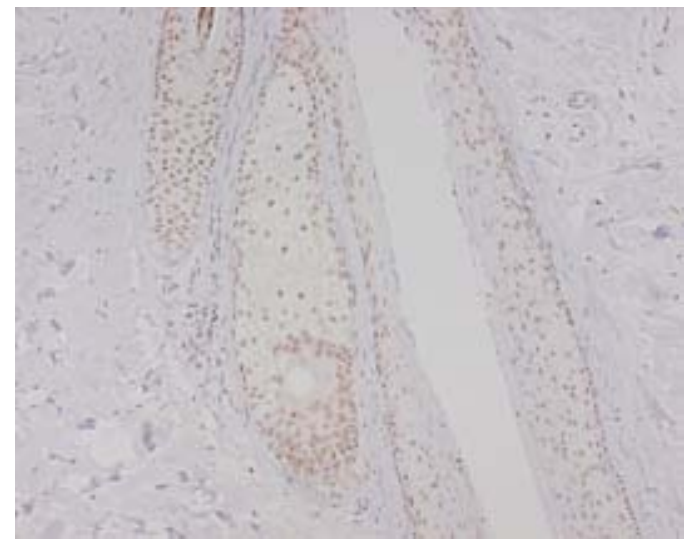

Fig. 1. Immunostaining of normal skin appendages with PRB. Nuclear staining of secretory cells of hair follicules and sebaceous glands. Original magnification $(\times 200)$.

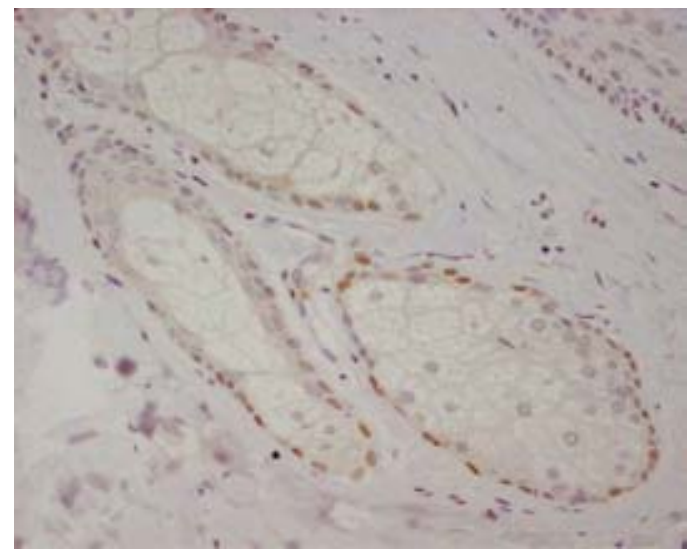

Fig. 2. Immunostaining of normal sebaceous glands with ER $\alpha$. ER $\alpha$ was positive in nuclei of basal cells but completely negative in nuclei of sebaceous lobule. Original magnification $(\times 400)$.

of hair follicles were negative in all the cases examined (Fig. 3, 4a). There were no significant differences between male and female subjects (Table 4).

In epidermis, immunoreactivity of all steroid hormone receptors was detected, with PRB immunoreactivity being the most frequently detected.

\section{Sweat gland neoplasms}

Results are summarized in Table 5. All of the sweat glands neoplasms, except for one case of extramammary Paget's disease, were positive for PRB, as in nonpathological sweat glands. PRA was positive in $86.7 \%$ (26/30) of the benign neoplasms and 50\% (6/12) of malignant tumors arising from sweat glands. In skin

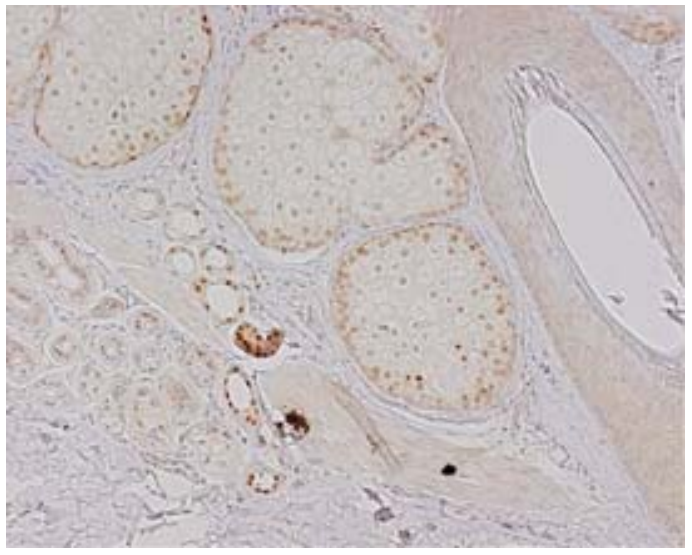

Fig. 3. Immunostaining of normal skin appendages with $A R$. Nuclear staining of sebaceous glands and secretary cells sweat glands, but negative staining in outer rooth sheath cells of hair follicle. Original magnification $(\times 200)$.

appendage neoplasms, both ER $\alpha$ and ER $\beta$ immunoreactivity tended to be relatively low. The ratio of AR positive cases in normal sweat glands $(91.3 \%)$ was significantly higher than in benign sweat gland neoplasms $(66.7 \%)(P<0.05)$ (Fig. 4b). AR-positive cases in malignant sweat gland neoplasms were not different from benign tumors $(66.7 \%)$ and normal sweat glands in this study (Fig. 4c). The proportion of the sex steroid hormone receptor positive cases in sweat gland neoplasms was summarized in Table 6.

\section{Sebaceous gland neoplasms}

Results were summarized in Table 7. ER $\alpha$ immunoreactivity was significantly lower in benign tumors $(25.0 \%)$ than basal cells of normal sebaceous glands $(82.6 \%)(P<0.01)$ (Fig. 5). ER $\beta$ immunoreactivity was negative in any of sebaceous glands neoplasms examined in this study. But there were no significant differences between non-pathological sweat glands and neoplasms. The number of PRA positive cases was relatively low $(25.0 \%)$. The great majority $(87.5 \%)$ of benign sebaceous neoplasms was positive for AR and PRB, but there were no significant differences between benign tumors and non-pathological sebaceous glands.

\section{Discussion}

In this study, we examined immunoreactivity of various steroid hormone receptors in non-pathological 
(a)

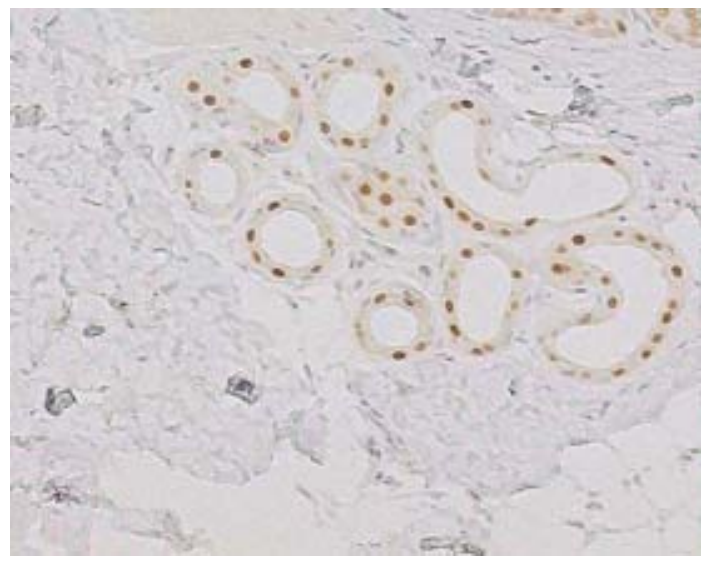

(b)

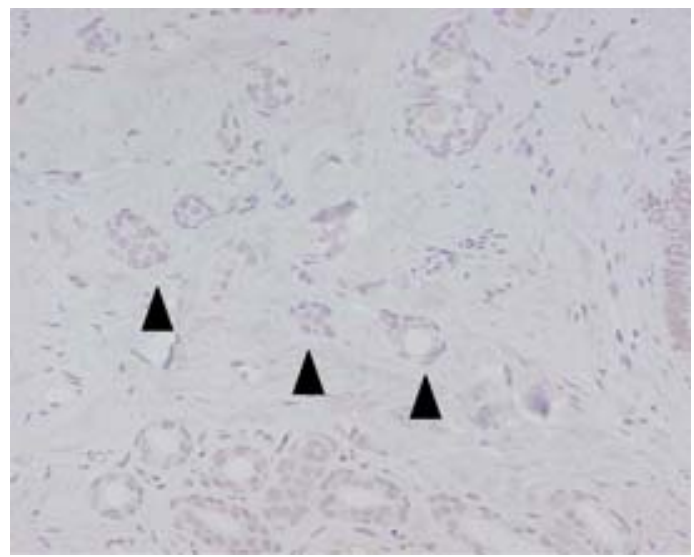

(c)

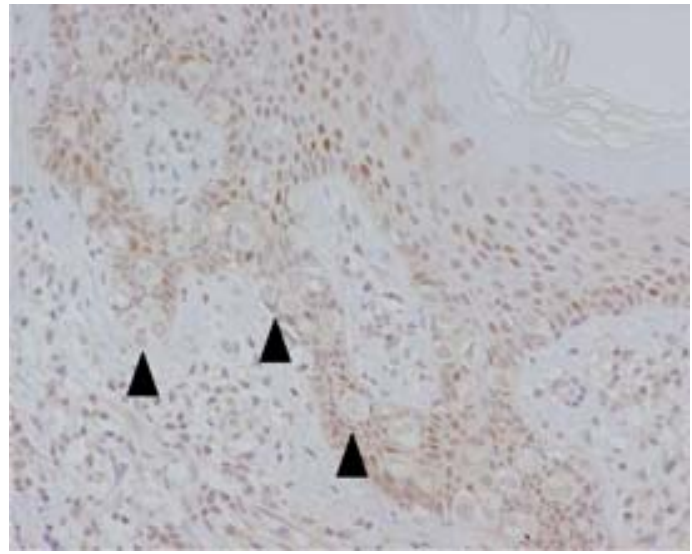

Fig. 4. Immunostaining of normal sweat glands and sweat gland neoplasms with AR. Variable staining of normal sweat glands (a), but negative staining in benign (syringoma) (b) and malignant (extramammary Paget's disease) (c) sweat gland neoplasms. Original magnification $(\times 400)$.

skin appendages from both sexes and skin appendage neoplasms. Expression of sex steroid hormone receptors examined in this study has been reported in various normal human organs [27-32]. In the skin, Thornton
Table 5. The proportion of the sex steroid hormone receptor positive cases in normal sweat glands and sweat gland neoplasms

\begin{tabular}{lccc}
\hline & $\begin{array}{c}\text { Normal } \\
\text { sweat glands } \\
\text { No. }(\%)\end{array}$ & $\begin{array}{c}\text { Benign } \\
\text { sweat gland } \\
\text { neoplasms } \\
\text { No. }(\%)\end{array}$ & $\begin{array}{c}\text { Malignant } \\
\text { sweat gland } \\
\text { neoplasms } \\
\text { No. }(\%)\end{array}$ \\
\hline ER $\alpha$ & $6 / 21(28.6)$ & $6 / 30(20.0)$ & $4 / 12(33.3)$ \\
ER $\beta$ & $9 / 23(39.1)$ & $8 / 30(26.7)$ & $3 / 12(25.0)$ \\
PRA & $13 / 22(59.1)$ & $26 / 30(86.7)$ & $6 / 12(50.0)$ \\
PRB & $21 / 22(95.5)$ & $30 / 30(100)$ & $11 / 12(91.7)$ \\
AR & $21 / 23(91.3)^{*}$ & $20 / 30(66.7)^{*}$ & $8 / 12(66.7)$ \\
\hline
\end{tabular}

*: $P<0.05$

(a)

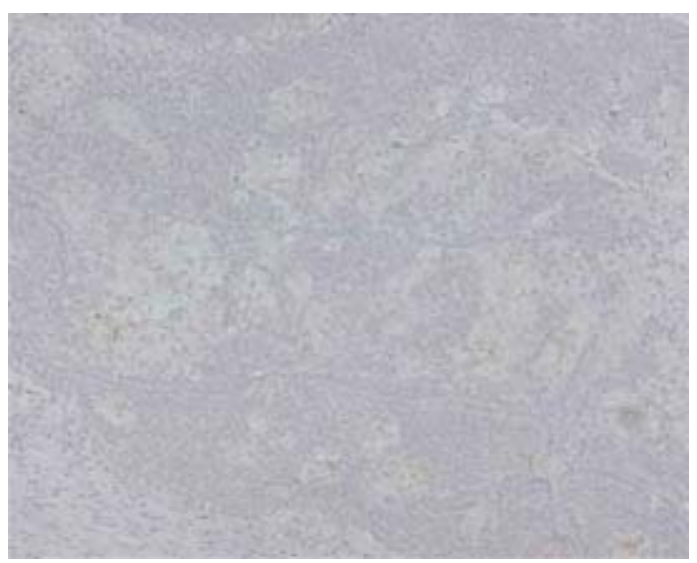

(b)

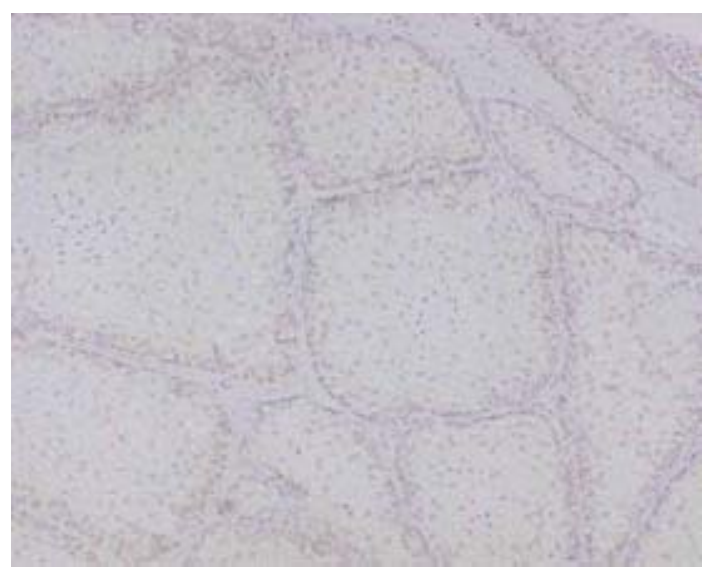

Fig. 5. Immunostaining of sebaceous gland neoplasms with $\mathrm{ER} \alpha$. Negative staining in benign (sebaceoma (a), sebaceous adenoma (b)) sebaceous gland neoplasms. But variable staining of basal cells of normal sebaceous glands (Fig. 2). Original magnification $(\times 200)$.

et al. demonstrated the presence of these receptors in scalp skin [23]. But to the best of our knowledge the systemic evaluation of these steroid receptors in human skin and skin appendage neoplasms have yet to be 
Table 6. The proportion of the sex steroid hormone receptor positive cases in each sweat gland neoplasms

\begin{tabular}{|c|c|c|c|c|c|}
\hline & $\mathrm{ER} \alpha$ & $\mathrm{ER} \beta$ & PRA & PRB & AR \\
\hline \multicolumn{6}{|l|}{ Eccrine/begin } \\
\hline Eccrine poroma & $0 / 6(0)$ & $0 / 6(0)$ & $5 / 6(83.3)$ & $6 / 6(100)$ & $3 / 6(50.0)$ \\
\hline Eccrine hidrocystoma & $1 / 6(16.7)$ & $3 / 6(50.0)$ & $5 / 6(83.3)$ & $6 / 6(100)$ & $4 / 6(66.7)$ \\
\hline Eccrine spiradenoma & $0 / 3(0)$ & $2 / 3(66.7)$ & $3 / 3(100)$ & $3 / 3(100)$ & $1 / 3(33.3)$ \\
\hline Clear cell hidradenoma & $1 / 3(33.3)$ & $0 / 3(0)$ & $1 / 3(33.3)$ & $3 / 3(100)$ & $2 / 3(66.7)$ \\
\hline Syringoma & $1 / 3(33.3)$ & $1 / 3(33.3)$ & $3 / 3(100)$ & $3 / 3(100)$ & $1 / 3(33.3)$ \\
\hline \multicolumn{6}{|l|}{ Apocrine/ benign } \\
\hline Mixed tumor & $3 / 6(50.0)$ & $2 / 6(33.3)$ & $6 / 6(100)$ & $6 / 6(100)$ & $6 / 6(100)$ \\
\hline Syringocystadenoma papilliferum & $0 / 2(0)$ & $0 / 2(0)$ & $2 / 2(100)$ & $2 / 2(100)$ & $2 / 2(100)$ \\
\hline Apocrine adenoma & $0 / 1(0)$ & $0 / 1(0)$ & $1 / 1(100)$ & $1 / 1(100)$ & $1 / 1(100)$ \\
\hline \multicolumn{6}{|l|}{ Eccrine/ malignant } \\
\hline Microcystic adnexal carcinoma & $1 / 1(100)$ & $1 / 1(100)$ & $1 / 1(100)$ & $1 / 1(100)$ & $1 / 1(100)$ \\
\hline \multicolumn{6}{|l|}{ Apocrine/ malignant } \\
\hline Extramammary Paget's disease & $2 / 7(28.6)$ & $1 / 7(14.3)$ & $4 / 7(57.1)$ & $6 / 7(85.7)$ & $5 / 7(71.4)$ \\
\hline Sweat gland carcinoma & $1 / 4(25.0)$ & $1 / 4(25.0)$ & $1 / 4(25.0)$ & $4 / 4(100)$ & $2 / 4(50.0)$ \\
\hline
\end{tabular}

Table 7. The proportion of sex steroid hormone receptor positive cases in normal sebaceous gland and sebaceous gland neoplasms

\begin{tabular}{lccc}
\hline & $\begin{array}{c}\text { Differentiated } \\
\text { cells of } \\
\text { sebaceous glands } \\
\text { No. }(\%)\end{array}$ & $\begin{array}{c}\text { Basal } \\
\text { cells of } \\
\text { sebaceous lobules } \\
\text { No. }(\%)\end{array}$ & $\begin{array}{c}\text { Benign } \\
\text { sebaceous gland } \\
\text { neoplasms } \\
\text { No. }(\%)\end{array}$ \\
\hline ER $\alpha$ & $6 / 21(28.6)$ & $6 / 30(20.0)$ & $4 / 12(33.3)$ \\
ER $\beta$ & $9 / 23(39.1)$ & $8 / 30(26.7)$ & $3 / 12(25.0)$ \\
PRA & $13 / 22(59.1)$ & $26 / 30(86.7)$ & $6 / 12(50.0)$ \\
PRB & $21 / 22(95.5)$ & $30 / 30(100)$ & $11 / 12(91.7)$ \\
AR & $21 / 23(91.3)^{*}$ & $20 / 30(66.7)^{*}$ & $8 / 12(66.7)$ \\
\hline
\end{tabular}

$*: P<0.01$

reported.

Human sweat gland is analogous to the mammary gland in its development [4]. Therefore, sweat gland neoplasms of the skin, especially malignant neoplasms, sometimes stimulate histological features of ductal carcinoma of the breast. Differential diagnosis between primary sweat gland carcinoma and metastatic breast carcinoma to the skin is sometimes difficult in histopathological examination. The differentiation between these lesions, which is crucial for clinical staging, management, and prognosis of the patient, also can be occasionally difficult [34-36]. Several investigators proposed the use of sex steroid receptors to differentiate primary sweat gland neoplasms from metastatic breast cancer to the skin $[13,35,36]$. However, it is also very important to recognize that primary neoplasms of skin appendage also expressed sex steroid receptors.

In this study, apocrine glands were not available for examination in any of the tissue sections of normal skin examined. Choudhry et al. reported AR-positive cases were high in apocrine sweat gland, as well as eccrine sweat gland [26]. This finding also suggests that functions of both apocrine and eccrine sweat glands may be modulated by sex steroids. AR was detected in the great majority of normal eccrine sweat glands (91.3\%) examined in our present study. PRB immunoreactivity was also detected in non-pathological eccrine sweat glands in $95.5 \%$ of the cases, but further investigations are required to clarify the possible roles of progesterone in regulation of human skin appendage functions.

Both ER and PR have been reported to be detected in some of the sweat gland neoplasms [13-19], but their isoforms have not been examined. ER $\beta$, which is widely distributed throughout the body [28], was detected in some sweat gland neoplasms. On the other hand, PRB was almost always expressed in sweat gland neoplasms in our series, and the ratio was relatively higher than that of PRA. However, the number of PRA and PRB positive cases was not significantly different between non-pathological sweat glands and malignant sweat gland neoplasms. This finding also suggests that progesterone does not necessarily influence growth 
of malignant sweat gland neoplasms. PRA immunoreactivity was frequently more positive in benign sweat gland tumors than in non-pathological sweat glands. Wallace et al. [33] demonstrated that PR was detected in $89 \%$ of syringoma, and that progesterone may influence growth of syringoma cells. Therefore these findings in our present study also suggest that progesterone may influence growth of these benign sweat gland neoplasms through PRA but it awaits further investigations for clarification.

AR immunoreactivity was detected in $71 \%$ of the cases of extramammary Paget's disease. Previous studies also demonstrated that AR was detected in 54\% [14] and $80 \%$ [15] of extramammary Paget's disease. ER $\alpha$ was detected in $29 \%$ of extramammary Paget's disease in our series. However, the positivity of AR in sweat gland neoplasms both benign and malignant including extramammary Paget's disease was not necessarily high. Immunoreactivity tended to be lower than that in non-pathological sweat glands. These findings indicated that AR has an important role in maintenance of normal sweat gland, and the decrease of AR immunoreactivity may result in development of neoplasm.

Sebaceous glands have been considered one of the target organs of androgen and estrogen [5]. In addition, progesterone may modulate the function of normal sebaceous structures based on the results of our present study. In our present study, AR immunoreactivity was detected in all basal and differentiated cells. This finding is consistent with the results of other studies which identified AR in sebaceous glands of normal skin [26, $36,37]$. These results also indicated that androgen is considered the dominant hormone influencing the development and/or physiology of sebaceous glands. PRB immunoreactivity was consistently detected in sebaceous glands, both in differentiated glandular cells and basal cells. ER $\alpha$ immunoreactivity was frequently detected only in basal cells of normal sebaceous glands in our study. Therefore, not only androgen but also progesterone and/or estrogen, may regulate hormonerelated physiology and/or development of sebaceous glands, especially through PRB and ER $\alpha$.

AR was also shown to be expressed in sebaceous gland neoplasms, including adenomas, carcinomas, and sebaceous nevi [18, 38]. Hamilton et al. [38] reported that congenital hamartoma with sebaceous glands consistently expressed AR during puberty. Our results also demonstrated that both AR and PRB were well preserved even in benign neoplasms, but the frequency of ER $\alpha$ was decreased. Androgen is normally considered the major regulator of human hair growth with paradoxically different effects on hair follicles depending on their body site. For instance, androgens incrementally stimulate the size of hair follicles on the face and trunk but not in other portions of the body $[7,39]$. In addition, several studies demonstrated the correlation between androgen and hair growth, especially alopecia $[39,40]$. Hence, neither the previous report [26] nor our present study demonstrated the AR expression in outer root sheath of normal hair follicles. On the other hand, ER $\alpha(42.9 \%)$, PRA $(26.3 \%)$ and PRB $(94.1 \%)$ were detected in structures of outer root sheath of hair follicles. These discrepancies of androgenic action may be explained as follows; 1) The expression level of AR was low in our study, and examination in the disease status, such as alopecia, may clarify possibility of correlation between androgen and hair growth; 2) AR expression may be influenced by the body sites examined. AR was reported as positive on non-genital skin [26]; 3) androgenic actions may be indirectly regulated by other hormones, including estrogen and progesterone, because ER $\alpha$, PRA and PRB are all expressed in these cells.

Sex steroids are considered to play important roles in regulation of normal skin appendage function and pathogenesis and/or development of its neoplasm and the status of the great majority of sex steroid hormone receptors was maintained throughout the process of neoplastic transformation of skin appendages, except for AR and ER $\alpha$ in sweat and sebaceous gland neoplasms.

\section{Acknowledgement}

This work was supported in part by Health and Labor Science Research Grants for Risk Analysis Research on Food and Pharmaceuticals (H13-Seikatsu-013) from Ministry of Health, Labor and Welfare of Japan. 


\section{References}

1. Howard BA, Gusterson BA (2000) Human breast development. J Mammary Gland Biol Neoplasia 2: 119-137.

2. von Schoultz B, Soderqvist G, Cline M, von Schoultz E, Skoog L (1996) Hormonal regulation of the normal breast. Maturitas 23: 23-25.

3. Shyamala G (1999) Progesterone signaling and mammary gland morphogenesis. J Mammary Gland Biol Neoplasia 1: 89-104.

4. Sadler TW (1995) Langman's Medical Embryology, $7^{\text {th }}$ ed, p 373, Lippincott Williams \& Wilkins, Maryland.

5. Strauss JS, Kligman AM, Pochi PE (1962) The effect of androgens and estrogens on human sebaceous glands. J Invest Dermatol 39: 139-155.

6. Pochi PE, Strauss JS (1969) Sebaceous gland response in man to the administration of testosterone, D4androstenedione, and dehydroisoandrosterone. J Invest Dermatol 52: 32-36.

7. Pochi PE, Strauss JS (1974) Endocrinologic control of the development and activity of the human sebaceous gland. J Invest Dermatol 62: 191-201.

8. Thody AJ, Shuster S (1989) Control and function of sebaceous glands. Physiol Rev 69: 383-416.

9. Schmidt JB, Binder M, Demschik G, Bieglmayer C, Reiner A (1996) Treatment of skin aging with topical estrogens. Int J Dermatol 35: 669-674.

10. Dunn LB, Damesyn M, Moore AA, Reuben DB, Greendale GA (1997) Does estrogen prevent skin aging? Results from the First National Health and Nutrition Examination Survey (NHANES I). Arch Dermatol 133: 339-342.

11. Sator PG, Schmidt JB, Sator MO, Huber JC, Honigsmann H (2001) The influence of hormone replacement therapy on skin aging: a pilot study. Maturitas 39: 43-55.

12. Shah MG, Maibach HI (2001) Estrogen and skin. An overview. Am J Clin Dermatol 2: 143-150.

13. Busam KJ, Tan LK, Granter SR (1999) Epidermal growth factor, estrogen, and progesterone receptor expression in primary sweat gland carcinomas and primary and metastatic mammary carcinomas. Mod Pathol 12: 786-793.

14. Diaz de Leon E, Carcangiu ML, Prieto VG, McCue PA, Burchette JL, To G, Norris BA, Kovatich AJ (2000) Extramammary Paget disease is characterized by the consistent lack of estrogen and progesterone receptors but frequently express androgen receptor. $\mathrm{Am}$ J Clin Pathol 113: 572-575.

15. Fujimoto A, Takata M, Hatta N, Takehara K (2000) Expression of structurally unaltered androgen receptor in extramammary Paget's disease. Lab Invest 80: 1465-1471.
16. Swanson PE, Mazoujian G, Mills SE, Campbell RJ, Wick MR (1991) Immunoreactivity for estrogen receptor protein in sweat gland tumors. Am J Surg Pathol 15: 835-841.

17. Voytek TM, Ricci A Jr, Cartun RW (1991) Estrogen and progesterone receptors in primary eccrine carcinoma. Mod Pathol 4: 582-585.

18. N Shikata, I Kurokawa, H Andachi, A Tsubura (1995) Expression of androgen receptors in skin appendage tumors; An immunohistocemical study. J Cutan Pathol 22: $149-153$.

19. Lloveras B, Googe PB, Goldberg DE, Bhan AK (1991) Estrogen receptors in skin appendage tumors and extramammary Paget's disease. Mod Pathol 4: 487-490.

20. Mazoujian G, Margolis R (1988) Immunohistochemistry of gross cystic disease fluid protein (GCDFP-15) in 65 benign sweat gland tumors of the skin. Am J Dermatopathol 10: 28-35.

21. Swanson PE, Cherwitz DL, Newmann MP, Wick MR (1987) Eccrine sweat gland carcinoma: a histologic and immunohistochemical study of 32 cases. J Cutan Pathol 14: 65-86.

22. Zuk JA, West KP, Fletcher A (1988) Immunohistochemical staining patterns of sweat glands and their neoplasms using monoclonal antibodies to keratins. J Cutan Pathol 15: 8-17.

23. Thornton MJ, Taylor AH, Mulligan K, Al-Azzawi F, Lyon CC, O’Driscoll J, Messenger AG (2003) Oestrogen receptor beta is the predominant oestrogen receptor in human scalp skin. Exp Dermatol 12: 181-190.

24. Shin R-W, Iwaki T, Kitamoto T, Tateishi J (1991) Methods in laboratory investigation: Hydrated autoclave pretreatment enhances TAU immunoreactivity in formalin-fixed normal and Alzheimer's disease brain tissues. Lab Invest 64: 693-702.

25. Blauer M, Vaalasti A, Pauli SL, Ylikomi T, Joensuu T, Tuohimaa P (1991) Location of androgen receptor in human skin. J Invest Dermatol 97: 264-268.

26. Choudhry R, Hodgins MB, Van der Kwast $\mathrm{TH}$, Brinkmann AO, Boersma WJ (1992) Localization of androgen receptors in human skin by immunohistochemistry: implications for the hormonal regulation of hair growth, sebaceous glands and sweat glands. $J$ Endocrinol 133: 467-475.

27. Enmark E, Gustafsson JA (1998) Estrogen receptor $\beta$ - a novel receptor opens up new possibilities for cancer diagnosis and treatment. Endocr Related Cancer 5: 213-222.

28. Ruizeveld de Winter JA, Trapman J, Vermey M, Mulder E, Zegers ND, van der Kwast TH (1991) Androgen receptor expression in human tissues: an immunohistochemical study. J Histochem Cytochem 39: 927936. 
29. Kimura N, Mizokami A, Oonuma T, Sasano H, Nagura $\mathrm{H}$ (1993) Immunohistochemical localization of androgen receptor with polyclonal antibody in paraffinembedded human tissues. J Histochem Cytochem 41: 671-678.

30. Mosselman S, Polman J, Dijkema R (1996) ER $\beta$ : identification and characterization of a novel human estrogen receptor. FEBS Letters 392: 49-53.

31. Taylor AH, Al-Azzawi F (2000) Immunolocalization of estrogen receptor beta in human tissues. $\mathrm{J} \mathrm{Mol}$ Endocrinol 24: 145-155.

32. Wick MR, Goellner JR, Wolfe JT 3rd, Su WPD (1985) Adnexal carcinomas of the skin. I. Eccrine carcinomas. Cancer 56: 1147-1162.

33. Wallace ML, Longacre TA, Smoller ER (1995) Estrogen and progesterone receptors and anti-gross cystic disease fluid protein 15 (BRST-2) fail to distinguish metastatic breast carcinoma from eccrine neoplasms. Mod pathol 8: 897-901.

34. Bayer-Garner IB, Smoller B (2000) Androgen receptors: a marker to increase sensitivity for identifying breast cancer in skin metastasis of unknown primary site. Mod Pathol 13: 119-122.

35. Ress J, Shuster S (1981) Pubertal induction of sweat gland activity. Clin Sci 60: 689-692.

36. Bayer-Garner IB, Givens V, Smoller B (1999) Immunohistochemical staining for androgen receptors: a sensitive marker of sebaceous differentiation. $\mathrm{Am} \mathrm{J}$ Dermatopathol 21: 426-431.

37. Ebling FJ (1973) The effect of cyproterone acetate and oestradiol upon testosterone stimulated sebaceous activity in the rat. Acta Endocrinol 72: 361-365.

38. Hamilton KS, Johnson S, Smoller BR (2001) The role of androgen receptors in the clinical course of nevus sebaceous of Jadassohn. Mod Pathol 14: 539-542.

39. Ebling FJ (1990) Hair and Hair disease, p 267-299, Springer-Verlag, Berlin.

40. Sawaya ME, Price VH (1997) Different levels of 5alpha-reductase type I and II, aromatase, and androgen receptor in hair follicles of women and men with androgenic alopetica. J Invest Dermatol 109: 296-300. 